\title{
Satellite based yield and water use targets for horticultural crops grown in SE Australia
}

\author{
M. G. O’Connell, D. M. Whitfield, A. T. McAllister, \\ L. McClymont, M. Abuzar \& K. J. Sheffield \\ Department of Primary Industries, Victoria, Australia
}

\begin{abstract}
Satellite-based information was combined with field data to estimate crop water requirement and yield potential in 74 fields of commercial fruit and nut crops grown in the Shepparton and Sunraysia Irrigation Regions of northern Victoria, Australia during the 2011/12 irrigation season. Comparisons of irrigation water supply (grower practice) with satellite-based estimates of crop water requirement showed over-irrigation was commonplace. Comparisons of actual yield with regional- and crop-specific yield targets showed large gaps in production performance.

Similar conclusions were derived from a retrospective study of yield and water use data for dried vine fruit crops $(n=285)$ grown in Sunraysia during the period, 2002-2011.

Keywords: normalised difference vegetation index, crop water requirement, potential yield.
\end{abstract}

\section{Introduction}

Yield and water use targets provide an important means of benchmarking crop water inputs (irrigation + rainfall) against measures of crop water requirement (CWR), and of gauging yield outcomes against regional expectations.

Yield and CWR of horticultural crops depend on crop type, weather, and vegetation cover $(f)$. Effects of weather on CWR are provided by measures estimates of tall crop reference evapotranspiration (ETr) (Allen et al. [1]) and $f$ (Goodwin et al. [2]; Allen and Pereira [3]; Whitfield et al. [4]). Weather effects on yield must account for solar radiation and $f$ (Monteith [5]). O'Connell and Goodwin [6] observed a 4-5 fold range in $f$ in horticultural crops grown in 
Shepparton Irrigation Region of South Eastern Australia. Implications for both yield and water use are accounted for using satellite data in this study.

Values of $f$ have traditionally been acquired using labour intensive groundbased approaches. More recently, extensive affordable measures of $f$ have been derived from satellite-based measures of normalised difference vegetation index (NDVI) (Asrar et al. [7]; Trout et al. [8]).

Two studies were undertaken. Study 1 sought to establish regional, NDVIdependent yield and water use targets, based on weather data (solar radiation, evaporative demand), crop type and satellite-derived estimates of $f$, for apple, pear, peach, nectarine, apricot and almond crops grown in the Shepparton and Sunraysia Irrigation Regions of northern Victoria, Australia in 2011/12. ASTER data were used to supplement satellite measures following the demise of Landsat 5.

Study 2 involved a retrospective analysis of possible effects of variations in $f$ on yield and water use data for up to 10 years in the Sunraysia Irrigation Region. Those data were collected as part of routine benchmarking activities, and were typically used in attempts to relate farmer yields to irrigation water supply. Sunraysia benchmarking studies have been characteristically restricted by small sample sizes, and have not accounted for effects of $f$ on yield and/or crop water supply (CWS; irrigation + rainfall). Study 2 investigated the role of variations in $f$ on historical yield and water use outcomes for dried vine fruit grown in Sunraysia in the period, 2002-2011. We assumed in Study 2 that the frequency distributions of NDVI $(f)$ in the study period 2 did not vary significantly from those reported by Whitfield et al. [4].

\section{Materials and methods}

\subsection{Formulation of yield and water use targets}

Yield and water use targets were framed in terms of a model of seasonal changes in vegetation cover (O'Connell [9]), whereby major yield and water use processes were concentrated on a period of maximum vegetation cover. It was assumed that evapotranspiration and carbon assimilation during the major period of vegetation cover were the major determinants of CWR and yield, respectively.

Accordingly, phenophase data were used to describe the time achievement of maximum $f$, denoted $t_{\mathrm{MAX}}$, and its duration prior to time of harvest, $t_{\mathrm{H} \cdot} f$ during the period, $t_{\mathrm{MAX}}-t_{\mathrm{H}}$, was assumed constant.

The simplified vegetation model thereby described the time of major canopy development in mature perennial deciduous fruit and vine crops grown in northern Victoria, in terms of the period, $t_{\mathrm{MAX}}-t_{\mathrm{H}}$, and maximum vegetation cover, $f_{\text {MAX. }}$.

Daily estimates of $f$ between times, $t_{\mathrm{MAX}}$ and $t_{\mathrm{H}}$, were therefore estimated by the relationship, $f=f_{\mathrm{MAX}}$. Otherwise, we assumed, $f=0$.

Estimates of CWR were made using the standard relationship:

$$
\mathrm{CWR}=\sum \mathrm{ETc}=\sum \mathrm{Kc} \mathrm{ETr}
$$


Here Kc was the crop coefficient that relates daily crop water use (ETc) to measures of tall crop reference evapotranspiration, ETr (Allen et al. [1]), and summation, $\sum$, applied over the period, $t_{\mathrm{MAX}}-t_{\mathrm{H}}$.

\subsection{Study 1: comparison of yield and irrigation inputs against yield and water use targets in the Shepparton and Sunraysia Irrigation Regions (season 2011/12)}

\subsubsection{NDVI measurements}

Cloud-free Landsat-7 (path/row: 93/85, 95/84) and ASTER images were acquired on $1^{\text {st }}, 6^{\text {th }}$ and $22^{\text {nd }}$ January 2012 during the major period of irrigation activity in the 2011/12 growing season. ASTER data were used to supplement Landsat data after demise of the Landsat 5 in 2012. Landsat and ASTER data were sourced from USGS (http://edcsns17.cr.usgs.gov/EarthExplorer) and Geoscience Australia, respectively.

NDVI was calculated according to Rouse et al. [10] as:

$$
\mathrm{NDVI}=(\mathrm{NIR}-\mathrm{RED}) /(\mathrm{NIR}+\mathrm{RED})
$$

where NIR is near infrared radiation, and RED is visible radiation. Radiometric corrections were applied according to Chander et al. [11] to account for atmospheric effects and differences in sun-sensor geometry.

NDVI was calculated on a pixel-by-pixel basis and averaged for each site, avoiding pixels at field edges. All image processing was conducted using IDL 7.0 and ENVI 4.6.1 software (ITT Visual Information Solutions, Boulder, Colorado, USA).

NIR and RED characteristics vary slightly with source, with potentiallysignificant effects on estimates of NDVI (Xu and Zhang [12]). ASTER measures of NDVI were converted to their Landsat equivalents based on linear relationships derived between $\mathrm{NDVI}_{\text {Landsat }}$ and $\mathrm{NDVI}_{\mathrm{ASTER}}$.

\subsubsection{On-ground measures of yield and irrigation inputs}

Commercial orchard sites were selected to represent the diverse range of the major crop types grown in the Shepparton (apple, peach, nectarine, apricot, pear) and Sunraysia (almond) Irrigation Regions. Irrigation inputs were monitored using flow meters at each site. Crop water supply was measured as the sum of the volume of irrigation water + rainfall. Measures of local rainfall were obtained from the Bureau of Meteorology (www.bom.gov.au/climate/data) for weather stations sited at Tatura $\left(36.7^{\circ} \mathrm{S}, 145.5^{\circ} \mathrm{E}\right.$, elev. $\left.114 \mathrm{~m}\right)$ and Mildura $\left(34.2^{\circ} \mathrm{S}, 142.1^{\circ} \mathrm{E}\right.$, elev. $\left.50 \mathrm{~m}\right)$.

The time of achievement of maximum canopy development $\left(\mathrm{t}_{\mathrm{MAX}}\right)$ at each site was obtained from on-site observations. $t_{H}$ was sourced from grower records. Daily fractional radiation interception of target crops $\left(f_{\mathrm{MAX}}\right)$ was measured according to methods described by Goodwin et al. [2]. Total radiation interception during the growing season $\left(\mathrm{S}_{\mathrm{GS}}\right)$ was calculated according to:

$$
\mathrm{S}_{\mathrm{GS}}=\sum\left(f_{\mathrm{MAX}} \cdot \mathrm{S}\right)
$$


where, S was daily solar radiation, and summation, $\sum$, applied over the period, $t_{\mathrm{MAX}}-t_{\mathrm{H}}$.

Measures of crop yield were obtained from grower records. Yield measures were related to $\mathrm{S}_{\mathrm{GS}}$ on the assumption that $\mathrm{S}_{\mathrm{GS}}$ accounts for the main period of photosynthate accrued by the fruit (O'Connell [9]).

Estimates of maximum yield ( $Y_{\mathrm{MAX}}$ ) for apple, pear, peach and nectarine were taken from relationships linking yield and $\mathrm{S}_{\mathrm{GS}}$ described by O'Connell [9]. Estimates of $Y_{\text {MAX }}$ for almond were based solely on measures of $f_{\text {MAX }}$ in order to make comparisons with data of Lampinen et al. [13].

NDVI-dependent estimates of Kc were derived as described by Whitfield et al. [4] for the period, $t_{\mathrm{MAX}}-t_{\mathrm{H}}$, which represents the main period of irrigation activity.

Estimates of ETr (Allen et al. [1]) were derived from daily weather data sourced from the Bureau of Meteorology.

\subsection{Study 2: retrospective analysis of yield and water use for dried vine fruit, Sunraysia (2002--2011)}

Measures of yield and irrigation water use for dried vine fruit crops $(n=285)$ in Sunraysia, Victoria during the period, 2002-2010, were sourced from studies reported by Ratna and Pollock [14].

Season-dependent estimates of CWR were derived for crops with low, average and high levels of vegetation cover in order to formulate respective estimates of CWR and $Y_{\mathrm{MAX}}$. Estimates of low, average and high levels of vegetation cover was sourced from Whitfield et al. [4] using regional NDVI values $\left(10^{\text {th }}\right.$ percentile, median, $90^{\text {th }}$ percentile values, respectively) for dried vine fruit crops $(n=457)$ acquired during the main growing period. Crop water requirement for the non-growing season was calculated using $\mathrm{Kc}=0.16$.

Season-specific estimates of $Y_{\text {MAX }}$ were estimated using procedures described above, using yield $/ \mathrm{S}_{\mathrm{GS}}$ relationships reported by O'Connell [9].

Measures of rainfall, evaporative demand and solar radiation were obtained from the Bureau of Meteorology weather station at Mildura. Phenophase data were sourced from Sommer et al. [15].

\section{Results and discussion}

\subsection{Study 1}

Eqn. (4) shows that NDVI measurements from ASTER were strongly related, but smaller, than measures obtained from Landsat:

$$
\mathrm{NDVI}_{\text {Landsat }}=0.966 \cdot \mathrm{NDVI}_{\mathrm{ASTER}}+0.067 n=10 ; \mathrm{R}^{2}=0.853
$$

Eqn. (4) supported observations of Xu and Zhang [12]. 
Table 1 shows the range in fractional radiation interception and duration of maximum vegetation cover phase for case study orchard crops in the Shepparton and Sunraysia Irrigation Regions. Large diversity was measured in both the level and duration of maximum vegetation cover among crops. Fractional daily radiation interception ranged 3-fold, from 0.39 to 0.90 , representing sparse and full foliage cover crops, respectively. Duration of maximum foliage cover ranged from 52 to 182 days, representing short-season and late-season crops, respectively.

Table 1: $\quad$ Range in fractional mid-season radiation interception $\left(f_{\mathrm{MAX}}\right)$ and duration of maximum vegetation cover phase $\left(t_{\mathrm{MAX}}-t_{\mathrm{H}}\right.$ period) of fruit and nut crops in Shepparton and Sunraysia Irrigation Regions, Victoria during the 2011/12 season.

\begin{tabular}{|l|c|c|c|}
\hline Crop & $f_{\text {MAX }}$ & $t_{\text {MAX }}-t_{\mathrm{H}}$ period (days) & Sites \\
\hline Apple & $0.48-0.88$ & $83-182$ & 8 \\
\hline Apricot & $0.87-0.90$ & 52 & 3 \\
\hline Peach & $0.39-0.81$ & $60-133$ & 36 \\
\hline Nectarine & $0.64-0.77$ & $72-113$ & 7 \\
\hline Pear & $0.63-0.68$ & $81-131$ & 3 \\
\hline Almond & $0.46-0.79$ & 182 & 17 \\
\hline
\end{tabular}

In the Shepparton Irrigation Region, rainfall during the 2011/12 irrigation season was $346 \mathrm{~mm}$ and evaporative demand, measured as tall reference crop evapotranspiration, $\mathrm{ET}_{\mathrm{R}}$, was $1,180 \mathrm{~mm}$. In Sunraysia, rainfall and $\mathrm{ET}_{\mathrm{R}}$ were 241 and $1,320 \mathrm{~mm}$, respectively. Irrespective of crop type, irrigation inputs varied widely. On a seasonal basis, irrigation inputs ranged from 140 to $1,435 \mathrm{~mm}$ (Shepparton) and 468 to $1,584 \mathrm{~mm}$ (Sunraysia).

Fig. 2 shows the relationship between crop water supply (irrigation + rainfall) against NDVI-derived CWR at the seasonal-scale on a field-by-field basis for orchard crops in the Shepparton Irrigation Region. The 1:1 line in fig. 2 represents CWS matching CWR.

CWS for many apple, pear, peach and nectarine crops fell well above the 1:1 line, while some peach crops had CWS approximating CWR. Heavy rainfall ( $\sim 160 \mathrm{~mm}$, late February 2012) contributed to the shift in CWS above CWR for some peach, nectarine and apple crops.

Irrigation scheduling by the majority of growers was based on local estimates of evaporative demand in combination with monitoring of available soil water in the wetted volume of irrigation emitters. Despite irrigation management being classed as moderate-to-high skill, three apple and one pear crop received CWS approximately 2-fold beyond site-specific CWR (fig. 2).

Data shown in fig. 2 emphasises the overall seasonal situation of supply and demand but does not reflect whether a crop has received the correct amount of water at the correct time (i.e. optimal irrigation scheduling). Whatever the cause of CWS $>>$ CWR, over irrigation suggests either too many irrigation events per season and/or too much water was applied per irrigation event. 


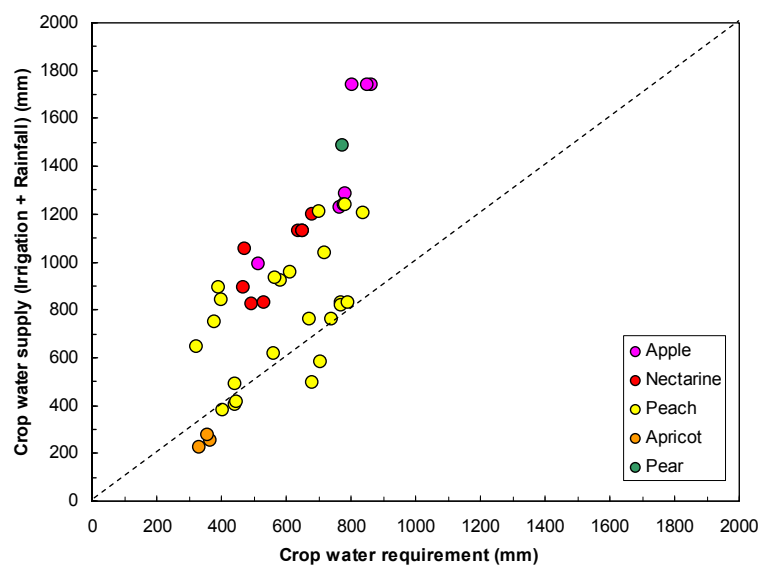

Figure 2: $\quad$ Relationship of crop water supply (irrigation + rainfall) against NDVI-derived crop water requirement for the period of full vegetation cover to fruit maturity (harvest) of fruit tree crops in the Shepparton Irrigation Region, Victoria during the 2011/12 season. The dashed line (1:1 relationship) represents crop water supply matching crop water requirement.

Fig. 3 shows the relationship between yield (dry weight) and cumulative seasonal intercepted radiation of fruit tree crops grown in Shepparton Irrigation Region. Actual yield matched potential yield for eight peach/nectarine crops, but the majority of apple, peach, nectarine, apricot and pear crops yielded below potential (fig. 3).

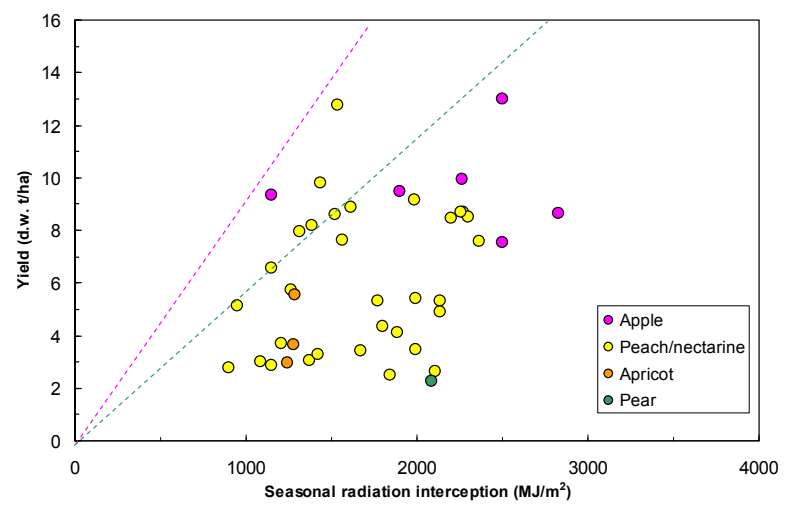

Figure 3: Relationship between yield and cumulative seasonal intercepted radiation of fruit tree crops in the Shepparton Irrigation Region, Victoria. Lines depict estimates of $Y_{\text {MAX }}$ for apple and pear (pink) and peach and nectarine (green). 
For almond, fig. 4 shows the relationship between crop water supply (irrigation + rainfall) against NDVI-derived CWR at the seasonal-scale on a field-by-field basis. The 1:1 line in fig. 4 represents CWS matching CWR. CWS for three almond crops fell well above the 1:1 line, while most almond crops had CWS approximating CWR (fig. 4).

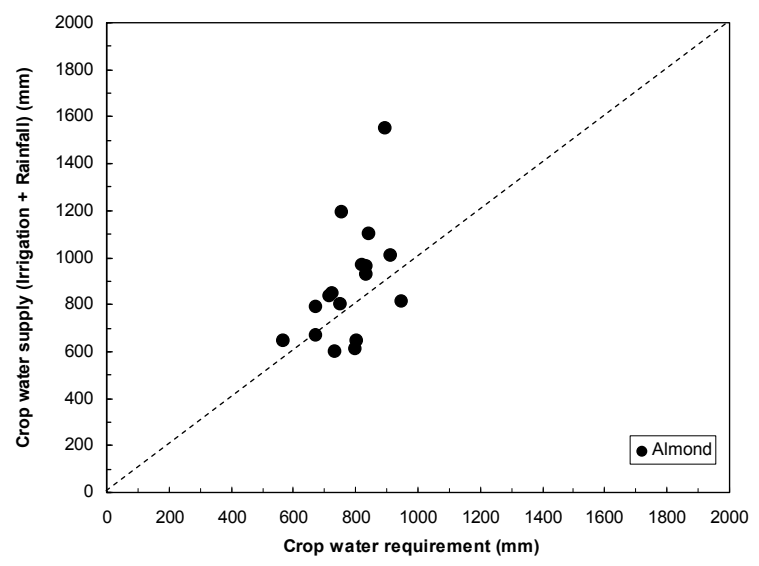

Figure 4: Relationship of crop water supply (irrigation + rainfall) against NDVI-derived crop water requirement for the period of full vegetation cover to fruit maturity (harvest) of almond crops in the Sunraysia Irrigation Region, Victoria during the 2011/12 season. The dashed line (1:1 relationship) represents crop water supply matching crop water requirement.

Irrigation scheduling by the majority of almond growers was based on local estimates of evaporative demand in combination with monitoring of available soil water in the wetted volume of irrigation emitters. Despite irrigation management being classed as moderate-to-high skill, one almond crop received CWS approximately 2-fold beyond site-specific CWR (fig. 4). However, it is noteworthy to observe that the majority of almond crops received irrigation inputs below the industry 'optimal irrigation' recommendation of $1,300 \mathrm{~mm}$ (13 ML/ha; Brown [16]).

Fig. 5 shows the relationship between yield and midday radiation interception during the mid-season period for almond crops $(n=17)$ grown in Sunraysia. Most crops performed below the yield target of $3.8 \mathrm{t} /$ ha set by the Australian almond industry (Brown [16]; Sommer and Pollock [17]), however five almond crops had optimal yield performance when indexed against vegetation cover. The remainder $(n=12)$ performed below potential yield, including hail damage crops.

The use of production potential 'yard-sticks' ( $Y_{\text {MAX }}$ lines; figs 3 and 5) helps identify the 'yield gap' between actual yield and potential yield and provides the framework for growers to objectively investigate the cause of poor yields beyond variation in vegetation cover. Many agronomic factors can decrease orchard 


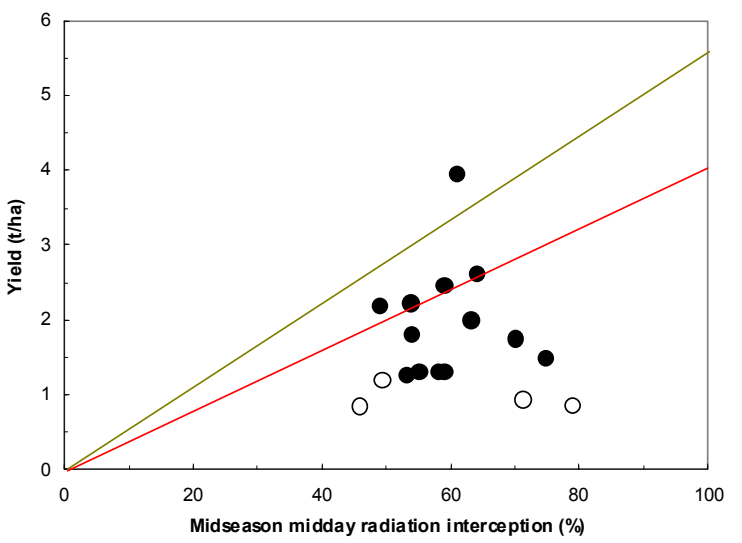

Figure 5: Yield versus mid-season midday radiation interception relationships for almond during the 2011/12 irrigation season in Sunraysia, Victoria. Lines depict estimates of $Y_{\text {MAX }}$ based on Australian (red line; Sommer and Pollock [17]) and Californian (green line; Lampinen et al. [13]) data. Note: open symbols represent hail damaged crops.

yield relative to potential yield, including water stress, pest and/or disease pressure, poor bloom, adverse weather conditions (e.g. hail damage, fig. 5) and poor nutrient management.

\subsection{Study 2}

Fig. 6 presents yield data of dried vine fruit for the period 2002/03 to 2010/11. Yield varied between years, ranging between 0 and $14.6 \mathrm{t} / \mathrm{ha}$. Yield was unrelated to available solar energy (data not shown) as consistency in growing season solar radiation (9-year average $=25 \mathrm{MJ} / \mathrm{m}^{2} / \mathrm{d}$ ) suggests yield potential $\left(Y_{\mathrm{MAX}}\right)$ was approximately the same in all years.

Estimated mean $(2.1 \mathrm{t} / \mathrm{ha})$ and maximum $(6.7 \mathrm{t} / \mathrm{ha})$ target yield fall within the bounds of yield observations recorded by irrigation benchmark surveys shown in fig. 6. Poor yield outcomes in 2010/11 (median yield $=1.7 \mathrm{t} / \mathrm{ha}$ ) were due to widespread fungal disease (grapevine powdery mildew) exacerbated by humid conditions following record growing season rainfall.

For dried vine fruit crops, midseason NDVI ranged 3-fold, $0.14<$ NDVI $<$ 0.65 , representing sparse and full foliage cover crops, respectively (data not shown). NDVI values for low, average and high $\left(10^{\text {th }}\right.$ percentile, median, $90^{\text {th }}$ percentile) levels of vegetation cover were $0.20,0.33$ and 0.47 , respectively. Fig. 7 presents crop water supply (irrigation + rainfall) of dried vine fruit for the period 2002/03 to 2010/11. Crop water supply ranged 3-fold, with a 9-year average of 8.2 ML/ha. Yield was unrelated to CWS (data not shown), suggesting large opportunity for water savings. NDVI-derived estimates of CWR for each 


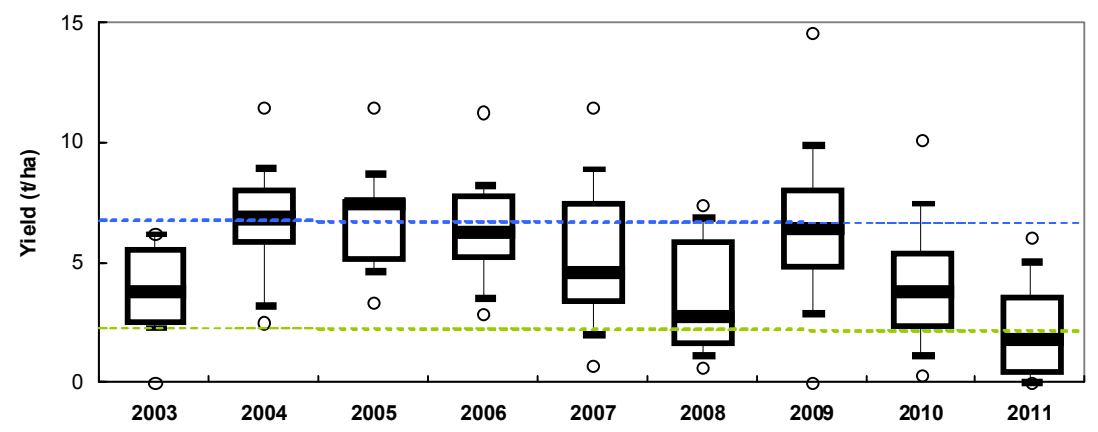

Figure 6: Box plots of crop yield for dried vine fruit crops $(n=285)$ in Sunraysia, Victoria during the period $2002 / 03$ to $2010 / 11$. Each box contains the $25^{\text {th }}-75^{\text {th }}$ percentiles, solid lines within the boxes show medians $\left(50^{\text {th }}\right.$ percentile), T bars show the bounds of the $10^{\text {th }}$ and $90^{\text {th }}$ percentiles and circles depict outliers (minimum and maximum yield values). Estimated mean (green line: $2.1 \mathrm{t} / \mathrm{ha}$ ) and maximum (blue line: $6.7 \mathrm{t} / \mathrm{ha}$ ) target yield is depicted.

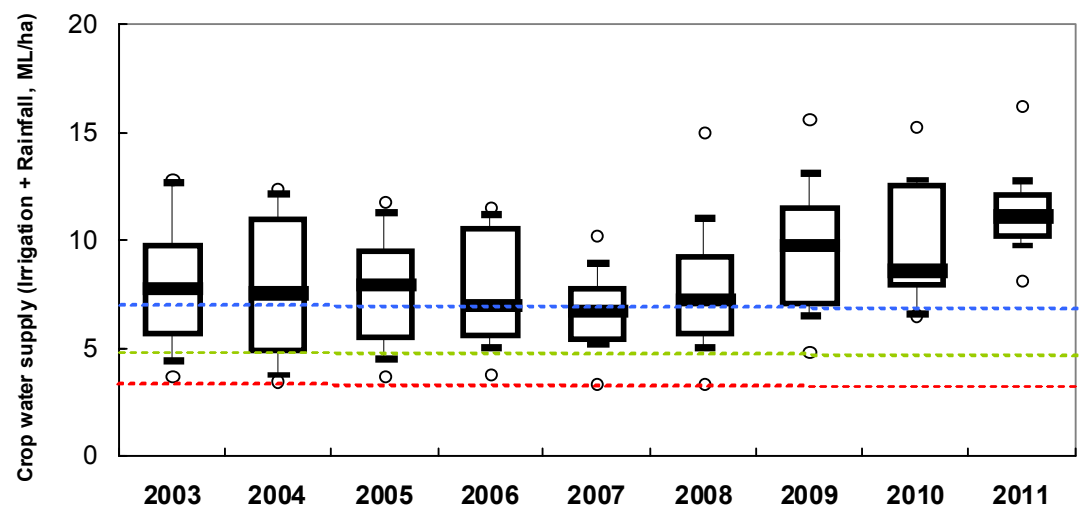

Figure 7: $\quad$ Box plots of crop water supply (irrigation + rainfall) for dried vine fruit crops $(n=285)$ in Sunraysia, Victoria during the period $2002 / 03$ to $2010 / 11$. Each box contains the $25^{\text {th }}-75^{\text {th }}$ percentiles, solid lines within the boxes show medians $\left(50^{\text {th }}\right.$ percentile $)$, $\mathrm{T}$ bars show the bounds of the $10^{\text {th }}$ and $90^{\text {th }}$ percentiles and circles depict outliers (minimum and maximum crop water supply values). Estimated crop water requirement is depicted for low (red line: 3.0 $\mathrm{ML} / \mathrm{ha}$ ), average (green line: $4.9 \mathrm{ML} / \mathrm{ha}$ ) and high (blue line: 6.6 $\mathrm{ML} / \mathrm{ha}$ ) vegetation cover conditions. 
year of the survey showed minimum, average and maximum CWR of 3.0, 4.9 and $6.6 \mathrm{ML} / \mathrm{ha}$, respectively. For a given level of vegetation cover, variation in CWR between seasons was negligible as evaporative demand remained stable.

The blue line shown in fig. 7 represents the CWR for the biggest dried vine fruit crops grown in Sunraysia, that is, the water requirement for high vegetation cover and long growing season crops. The 'water gap' between grower practice (crop water supply) and CWR (lines; fig. 7) suggests substantial water savings ( 3-5 ML/ha) are potentially available for the dried vine fruit industry.

This study identified substantial water savings are possible though improved irrigation management without penalising yield in the dried vine fruit industry of Sunraysia, Victoria. Comparison of current irrigation practice against estimated NDVI-dependent crop water requirement suggests most dried vine fruit crops require improved irrigation management.

\section{Conclusion}

This study compared yield and irrigation performance of fruit and nut crops grown in the Shepparton and Sunraysia Irrigation Regions of Victoria, Australia. Grower irrigation practice, measured as crop water supply (irrigation + rainfall) was indexed against satellite-derived NDVI-dependent crop water requirement. Over-irrigation was detected and yield performance varied widely. Most crops performed well below the regionally derived potential yield.

This study highlights the need for yield and water use targets to accompany practical irrigation benchmarking studies. Yield and water use targets provide context to irrigation and production data. Satellite-derived yield and water use targets based on NDVI were seen to be appropriate. This routine, affordable, scientifically-based approach provides the ability to deliver customised water use and yield targets for all crops within an irrigation district to support high standards of irrigation water management and improve agricultural productivity.

\section{Acknowledgements}

This research was financially support by Department of Primary Industries, Victoria. Growers in the Sunraysia and Shepparton Irrigation Regions provided access their orchard fields for water and canopy measurements and provision of yield data. Ben Brown, Almond Board of Australia provided grower liaison and industry advice. Linda Pollock and Richard Ratna (DPI Farm Services Victoria) and Richard Maxwell (DPI Spatial Sciences) provided field assistance and GIS skills.

\section{References}

[1] Allen, R.G., Walter, I.A., Elliot, R., Howell, T., Itenfisu, D. and Jensen, M. The ASCE Standardized Reference Evapotranspiration Equation, ASCEEWRI. 2005. 
[2] Goodwin, I., Whitfield, D.M. and Connor, D.J. Effects of tree size on water use of peach (Prunus persica L. Batsch). Irrigation Science 24, pp. 59-68, 2006.

[3] Allen, R.G. and Pereira, L.S. Estimating crop coefficients from faction of ground cover and height. Irrigation Science 28, pp. 17-34, 2009.

[4] Whitfield, D.M., O’Connell, M.G., McAllister, A., McClymont, L., Abuzar, M. and Sheffield, K. SEBAL-METRIC estimates of crop water requirement in horticultural crops grown in SE Australia. Acta Horticulturae 922, pp. 141-148, 2011.

[5] Monteith, J.L. Climate and the efficiency of crop production in Britain. Philosophical Transactions of the Royal Society of London, Series B 281, pp. 277-294. 1977.

[6] O'Connell, M.G. and Goodwin, I. Spatial variation of tree cover in microirrigated peach orchards. Acta Horticulturae 694, pp. 203-205, 2005.

[7] Asrar, G., Myneni, R.B. and Choudhury, B.J. Spatial heterogeneity in vegetation canopies and remote sensing of absorbed photosynthetically active radiation: A modeling study. Remote Sensing of Environment 41, pp. 85-103, 1992.

[8] Trout, T.J., Johnson, L.F. and Gartung, J. Remote sensing of canopy cover in horticultural crops. Hort Science 43, pp. 333-337, 2008.

[9] O’Connell, M.G. Satellite Based Yield-Water Use Relationships of Perennial Horticultural Crops. PhD Thesis, The University of Melbourne, Victoria, 2011.

[10] Rouse, J.W., Hass, R.H., Schell, J.A., and Deering D.W. Monitoring vegetation systems in the great plains with ERTS. Third NASA ERTS Symposium 1, pp. 309-317, 1973.

[11] Chander, G., Markham, B.L. and Helder, D.L. Summary of current radiometric calibration coefficients for Landsat MSS, TM, ETM+, and EO1 ALI sensors. Remote Sensing of Environment 113, pp. 893-903, 2009.

[12] $\mathrm{Xu}, \mathrm{H}$. and Zhang, T. Comparison of Landsat-7 ETM+ and ASTER NDVI measurements. Proceedings of Society of Photographic Instrumentation Engineers 8203, p. 82030K, 2010.

[13] Lampinen, B., Udompetaikul, V., Browne, G.T., Metcalf, S.G., Stewart, W.L., Contador, L., Negron, C. and Upadhyaya, S.K. A mobile platform for measuring canopy photosynthetically active radiation interception in orchard systems. Hort Technology 22, pp. 237-244, 2012.

[14] Ratna, R.D. and Pollock, L. Dried Vine Fruit Irrigation Benchmarking 2002-2011: Sustainable Landscapes Mallee-Irrigation. Department of Primary Industries: Mildura, 2011.

[15] Sommer, K.J., Hancock, F., Downey, M. and Goodwin, I. Impact of deficit irrigation on Sunmuscat production in Australia. Acta Horticulturae (submitted), 2012.

[16] Brown, B. Sustainable Optimisation of Australian Almond Production, Final Report. HAL project: AL07005, 2011.

[17] Sommer, K.J. and Pollock, L. Almond irrigation benchmarking 2002-2008 seasons. Department of Primary Industries: Mildura, 2008. 